\title{
WHAT THE SUPREME COURT DID NOT DO IN THE 1949 TERM-AN APPRAISAL OF CERTIORARI
}

\author{
By Fowler V. Harper $\dagger$ and Alan S. Rosenthal $\uparrow$
}

From time to time, surveys are made of the work of the Supreme Court for a particular term ${ }^{2}$ and a current series of annual articles reviews the Court's business term by term and comments on some of its institutional aspects. ${ }^{2}$ It is proposed in this article to examine the work which the Court might have done, but did not do during the 1949 term, i.e. the denial of petitions for writs of certiorari and the dismissal of appeals. ${ }^{3}$ It may be that the work which the Court doesn't do is as significant for the nation as the work which it does. When it decides a case involving important matters of public interest, it is making national policy. When it declines to review a case involving important issues, is it not also determining policy? To be sure, it may review and reverse a case next year involving the same issue. But it is also true that it may reverse itself next year, as a justice occasionally will complain. ${ }^{4}$ From the standpoint of national policy, it is not easy to find any difference.

It is well known that, quantitatively, denials and dismissals far exceed the number of cases accorded full review. For the 1949 term the Court wrote 94 opinions, ${ }^{5}$ the smallest number in many years. It refused to consider, either by denying certiorari or by dismissing the appeal, 1,033 cases, of which $597^{\circ}$ were on the appellate docket and

† Professor of Law, Yale Law School; formerly General Counsel, Federal Security Agency; formerly Solicitor, Department of the Interior; author of HARPER oN TORTS and various other books and articles.

$¥ A . B$., 1948, University of Pennsylvania; member of the third-year class, Yale Law School; Assistant In Instruction, Yale Law School.

1. See the symposium in 47 CoL. L. REv. 883-1008 (1948), reviewing the Court's work for the 1946 term.

2. The series of articles in the University of Chicago Law Review by John $P$. Frank, 15 U. of CHI. L. REv. 1 (1947) ; 16 U. of Chr. L. Rev. 1 (1948); 17 U. of CHI. L. Rev. 1 (1949) ; 18 U. OF CHI. L. REv. 1 (1950).

3. Although there is a technical distinction between the denial of a petition for a writ of certiorari and the dismissal of an appeal, for the purposes of this article they are treated together because of the Court's tendency to dispose of appeals in brief per curiam opinions.

4. "Respect for continuity in Law, where reasons for change are wanting, alone requires adherence to Trupiano [Trupiano v. United States, 334 U.S. 699 (1948)] and other decisions. Especially ought the Court not reinforce needlessly the instabilities of our day by giving fair ground for the belief that Law is the expression of chance-for instance, of unexpected changes in the Court's composition and the contingencies in the choice of successors." Justice Frankfurter, dissenting, in United States v. Rabinowitz, 339 U.S. 56 (1950).

5 . Including per curiam opinions.

6. Including 78 companion cases. 
$436^{7}$ on the miscellaneous dockets, by far the majority of the latter being in forma pauperis. A comparison with the previous year shows a larger number of opinions written in that term (114) and a slightly smaller number of denials (948) ${ }^{8}$ It might be noted that during the past term, the Court granted certiorari in 92 cases on the appellate docket and 7 on the miscellaneous dockets. At the term before, it granted 149 and 18.

Presumably all the cases which the Court reviews are important. There is no necessary converse presumption as to the cases which are not reviewed, for although the importance of the issues involved may be a ground for granting the petition, there are many reasons for denying the writ notwithstanding the presence of important public questions in the case. The operation of certiorari jurisdiction is largely behind a curtain. ${ }^{9}$

\section{How Certiorari Operates}

Since 1925, most of the work of the Supreme Court has been within its discretionary jurisdiction. ${ }^{10}$ Appeals are important, but they are vastly outnumbered by petitions for certiorari. Cases involving original jurisdiction account for but a minute fraction of the Court's work load. For a number of years the ratio of appeals to petitions for certiorari was about 1 to $5^{11}$ and that proportion appears to hold roughly for recent terms.

Congressional legislation in $1916^{12}$ had brought some relief to the Court from a burden which was becoming unmanageable. The Federal Employers Liability Act had greatly increased the Court's business with a run of cases, many of which could hardly be thought of sufficient importance to justify a claim on the time and energy of the highest court in the land. ${ }^{13}$ The 1916 Act was intended in part to reduce the compulsory review by relieving the Court from the obligation

7. Law Week reported 437 cases on the miscellaneous dockets in which certiorari was denied but the clerk of the Supreme Court reports the figure used in the text.

8. See the Report of the Director of the Administrative OfFice of the U.S. CourTs, 71-73 (1949).

9. There is only a small literature on certiorari. See Frankfurter AND LANDIs, The Bustness of THE Supreme COURT, 255-298 (1927); Boskey, Mechanics of the Supreme Court's Certiorari Jurisdiction, 46 CoL. L. REv. 255 (1946); and notes in 15 A.B.A.J. 681 (1929); 15 CALIF. S.B.J. 257 (1940); 36 CoL. L. REV. 472 (1936); 4 GEo. W.L. REv. 257 (1935); 17 GEo. L.J. 307 (1929); 15 N.Y.U.L.Q. 252 (1930).

10. 28 U.S.C. $\$ \$ 1251-1257$ (1946). See Boskey, supra note 9.

11. Ibid. (1948).

12. 39 STAT. 726 (1916), 28 U.S.C. \$\$338, 334 (1946), repealed, 62 STAT. 992

13. H.R. Rep. No. 794, 64th Cong., 1st Sess., 6905 (1916). See Frankfurter AND LANDIS, op. cit. supra note 9, at 206 et seq. 
of reviewing FELA cases which, in its judgment, presented unimportant issues. ${ }^{14}$ The statute went far to accomplish this result.

But the flow of business soon again caught up with the Court's capacity. In 1925, Congress at the urging of the Court ${ }^{15}$ vastly extended its power to control its business by shutting off numerous other sources of appeal as of right, confining such review to three sources, district courts, circuit courts of appeals and state courts. ${ }^{16}$ The types of cases from these courts were narrowly limited to the end that the Court could so regulate its work as to pass primarily on questions of widespread national significance.

This was the latitude which the Court desired. ${ }^{17}$ How is it working today? The present rule pertaining to certiorari provides:

"A review on writ of certiorari is not a matter of right, but of sound judicial discretion, and will be granted only where there are special and important reasons therefor. The following, while neither controlling nor measuring the Court's discretion, indicate the character of reasons which will be considered:

"(a) Where a state court has decided a federal question of substance not theretofore determined by this court, or has decided it in a way probably not in accord with applicable decisions of this court.

"(b) Where a circuit court of appeals has rendered a decision in conflict with the decision of another circuit court of appeals on the same matter; or has decided an important question of local law in a way probably in conflict with applicable local decisions; or has decided an important question of federal law which has not been but should be decided by this court; or has decided a federal question in a way probably in conflict with applicable decisions of this court; or has so far departed from the accepted and usual course of judicial proceedings, or so far sanctioned such a departure by a lower court, as to call for an exercise of this court's power of supervision.

"(c) Where the United States Court of Appeals for the District of Columbia has decided a question of general importance, or a question of substance relating to the construction or application

14. $I d$. at 213.

15. Chief Justice Taft was largely responsible for the 1925 legislation. A drafting Committee consisting of Justices Van Devanter, McReynolds and Sutherland are entitled to much of the technical credit. The measure was enacted primarily in deference to the prestige of Court sponsorship with critical examination only by Senator Walsh in the Senate. The legislative history of the Act is traced in FrankFurTer AND LANDIS, op. cit. supra note 9, at 255-298.

16. Among others, the Court of Claims had gradually developed as a fruitful source of work. Chief Justice Taft outlined the several sources of appeals, as of right, from the circuit court of appeals. Hearings before Senate Subcomnittee of the Committee on the Judiciary on S. 2060, 68th Cong., 1st Sess. 23 (1924), quoted, in part, in FRANKFURTER AND LANDIS, op. cit. sipra note 7, at 262-265.

17. See Hearings before the House Judiciary Committee on H.R. 8206, 68th Cong., 2d Sess. (1924), containing statements by Chief Justice Taft and Justices Van Devanter, McReynolds and Sutherland in support of the bill; and see also Hearings, supra note 14 . 
of the Constitution, or a treaty or statute, of the United States, which has not been but should be, settled by this court; or where that court has not given proper effect to an applicable decision of this court." 18

In the application of this rule the Court has regularly followed the so-called rule of four, i.e., if four justices so vote, the writ will be granted. ${ }^{19}$ All certiorari cases on the appellate docket are examined by each of the justices. Copies of the record and briefs are sent to all as a matter of routine. ${ }^{20}$ Cases on the miscellaneous docket, it seems, are sorted out in the office of the Chief Justice and those which appear to have important issues, circulated among the justices. ${ }^{21}$ Presumably there are two reasons for this practice. In the first place by far the largest number of these are in forma pauperis with but one copy of the record. In the second place, the Court's experience has indicated that an overwhelming number of such cases have no merit at all. ${ }^{22}$ Votes on all questions of grant or denial are taken at conference although the result does not appear in the Court's report except in so far as a justice "notes" his dissent which is done infrequently and presumably only when he feels strongly that the case should be reviewed. ${ }^{23}$ In the 1949 term, of the 1,033 cases summarily disposed of, dissents were noted in only 25 cases, 20 of which were on the appellate docket.

In considering the work of the Court which involves full review, it is noteworthy that there has been a steady decline in the number of

18. 28 U.S.C. Rule 38.5 (1946).

19. Mr. Justice Van Devanter in testifying before the Senate Judiciary subcommittee on the 1925 Act stated that the rule of four was already an established practice in certiorari cases although it appeared that occasionally the writ had been granted on a vote of three justices. Hearings before Senate Judiciary Subcommittee on S. 2061, 68th Cong., 1st Sess. (1924); and see Bailey v. Central Vermont R. Co., 319 U.S. 350,358 (1943).

A curious rule is applied if, through disqualification of justices or otherwise the Court cannot muster a quorum of six (28 U.S.C.A. $\$ 1$ ). It appears that if a majority of the qualified justices vote that the case should not be heard at the next term of court, the judgment of the court below is affirmed. See 28 U.S.C. $\$ 2109$ and see Prichard v. United States, 339 U.S. 974 (1950).

20. Justice Stone, The Chief Justice, 27 A.B.A.J. 407 (1941). 519 (1942).

21. See Chief Justice Stone, Functions of the Circuit Conferences, 28 A.B.A.J.

22. "In 1946, a total of 528 [petitions in forma panperis] were received. Most of these petitions came from prisoners, state and federal, who challenged the legality of their convictions or detention in post-trial proceedings. 455 such petitions were filed last [1948] term. In addition, requests for other kinds of relief, such as original writs of habeas corpus, mandamus, prohibition, and the so-called common law writ of certiorari, have mounted each year until they reached a peak of 249 last term. . . . Last term only 18 such cases, approximately $4 \%$ of the petitions were granted. . . This is not hard to account for, since most of the petitions are prepared by prisoners without legal assistance and are without legal merit." Chief Justice Vinson, Work of the Federal Courts, an address before the American Bar Association, Sept. 7, 1949, printed in 70 Sup. Ct. XIII, XV (1949).

23. "It becomes relevant here to note that failure to record a dissent from a denial of a petition for writ of certiorari in no wise implies that only the member of the Court who notes his dissent thought the petition should be granted." Justice Frankfurter in Maryland v. Baltimore Radio Show, 338 U.S. 912, 918 (1950). 
cases disposed of by opinion since the 1925 Act. During the five terms from 1926 to 1930, the Court rendered an average of 194 opinions per term. $^{24}$ For the five terms from 1932 to 1936 , it wrote an average of 183 opinions per term. ${ }^{25}$ For the five terms from 1945 to 1949, the average had dropped to 123 , the low point being 94 for the past term. ${ }^{26}$ Now it is clear that the purpose of the 1925 Act was to make it possible for the Court to regulate its business so that it can effectively discharge its obligations. It is not at all clear, however, that Congress desired or was willing to authorize the Court to reduce its work to the barest of bare minima. If, as this article contends, there are cases which deserve Supreme Court review but do not get it, it is a fair question whether the Court may not be under an obligation to keep the volume of its output up to a reasonable standard. And although, as every one knows, consideration of the record in certiorari cases makes enormous demands upon the Court's time, obviously the task is greater if the Court grants review and renders a full opinion.

\section{The Purple Curtain}

In cases involving a denial of certiorari it is difficult to know what goes on behind the purple curtain. We can probably assume that in a large majority of the cases, none of the reasons set forth in Rule 38 was present and this could account for the action taken. But no such inference can be safely drawn with respect to any particular case. The bar has been repeatedly warned against assumptions based on a denial of the writ. ${ }^{27}$ Although occasionally the Court ${ }^{28}$ or one of the justices ${ }^{29}$

24. This figure is based on the tables compiled by Frankfurter and Landis, The Business of the Supreme Court, October Term, 1930, 45 HARv. L. REv. 271, 273 (1931).

25. Frankfurter and Fisher, The Business of the Suprente Court, October Term, 1935, 1936, 51 HARv. L. REv. 577, 581 (1937).

26. Data taken from Frank's articles for the 1947, '48 and '49 terms and from U.S. LAW WEEK for the 1946 and ' 47 terms.

27. "The denial of a writ of certiorari imports no expression of opinion upon the merits of the case, as the bar has been told many times." Justice Holmes in United States v. Carver, 260 U.S. 482, 490 (1923).

"Our rules adopted to carry out the policy of the statutes granting the power to bring cases here by certiorari have apprised the Bar and the public that we will not take cases fully heard and adjudicated below for the mere purpose of reexamining the correctness of the result." Justice Roberts in Deputy v. Du Pont, 308 U.S. 488, 500 (1940).

". . . all that a denial of a petition for certiorari means is that fewer than four members of the Court thought it should be granted . . Justice Frankfurter, speaking for himself in State of Maryland v. Baltimore Radio Show, 338 U.S. 912, 918 (1950).

28. See Boskey, supra note 9, at 259-260 and cases cited. Occasionally, when the reasons are given, a petition for rehearing may correct the defect, as where the defect was jurisdictional. See, e.g., Brady v. Terminal R. Assoc., 302 U.S. 688 (1937). See Boskey, Finality of State Court Judgments under the Judicial Code 43 CoL. L. Rev. 1002, 1005 et seq. (1943).

29. Justice Rutledge in a seven page opinion expressed his reasons for joining in denial in Chase Nat'l Bank, Trustee v. Cheston, 332 U.S. 793, 794 (1947). 
will assign a reason for denial, the usual practice is merely a laconic announcement of the result. ${ }^{30}$ Even justices who feel strongly enough in opposition to note their dissent rarely state the grounds. ${ }^{31}$

During the past term Justice Frankfurter wrote a 13 page opinion on the denial of a writ of certiorari to explain again that such action could not be made the basis for a legitimate inference as to how the justices felt about the merits of the case. The occasion for this admonition involved a volatile civil liberty issue arising out of the Baltimore Radio Show case. ${ }^{32}$ A radio station in Baltimore had been punished for contempt of court by publication after a sensational broadcast of an alleged confession by an accused charged with an especially revolting murder of a little girl. The trial court held that the matters broadcast constituted "not merely a clear and present danger to the administration of justice, but an actual obstruction of the administration of justice, in that they deprived the Defendant James of his Constitutional right to have an impartial jury trial." ${ }^{33}$ The Court of Appeals of Maryland reversed on the ground that the power to punish for contempt is limited by the First and Fourteenth Amendments to the Federal Constitution. It is clear that vital issues were at stake. ${ }^{34} \mathrm{Mr}$. Justice Frankfurter himself said: "The issues considered by the Court of Appeals bear on some of the basic problems of a democratic society. Freedom of the press, properly conceived, is basic to our constitutional system. Safeguards for the fair administration of criminal justice are enshrined in our Bill of Rights. Respect for both of these indispensable elements of our constitutional system presents some of the most difficult and

30. "Since there are ... conflicting and to the uninformed, even confusing reasons for denying petitions for certiorari, it has been suggested from time to time that the Court indicate its reasons for denial. Practical considerations preclude. In order that the Court may be enabled to discharge its indispensable duties, Congress has placed the control of the Court's business, in effect, within the Court's discretion. If the Court is to do its work it would not be feasible to give reasons, however brief, for refusing to take these cases. The time that would be required is prohibitive, apart from the fact . . . that different reasons not infrequently move different members of the Court in concluding that a particular case at a particular time makes review undesirable." Justice Frankfurter in Maryland v. Baltimore Radio Show, 338 U.S. 912,918 (1950).

"To remain effective, the Supreme Court must continue to decide only those cases which present questions whose resolution will have immediate importance far beyond the particular facts and parties involved." Chief Justice Vinson, Work of the Federal Courts, an address before the American Bar Association, Sept. 7, 1949, printed in 70 Sup. Ct. XIII, XIV (1949).

31. Justices Frankfurter and Jackson dissented in six lines in Chase Nat'l Bank v. Cheston, 332 U.S. 793 (1947).

32. Baltimore Radio Show v. Maryland, 67 A.2d 497 (Md. 1949), cert. denied 338 U.S. 912 (1950).

33. From the statement by the trial court, quoted by Justice Frankfurter.

34. Note, 59 Yale L.J. 534 (1950). 
delicate problems . . . when they are before the Court for adjudication." 35

And yet Mr. Justice Frankfurter, in the course of his opinion does not tell us why the Court refused to review the case except that less than four justices so voted. He sets forth in an appendix included in his opinion a series of English authorities bearing on the problem, but we have no express statement of his own attitude toward it. One is somehow struck with one of his own statements, made, of course, with respect to the problem in the Baltimore Radio Show Case: "One of the demands of a democratic society is that the public should know what goes on in court . . . to the end that the public may judge whether our system of criminal justice is fair and right." 36

There are many speculative reasons, aside from those suggested in the Court's Rules, not all of which go to the merits, ${ }^{37}$ which might conceivably account for a denial. A case, for example, may result in a denial because a petition has been granted in a case involving the same question presented more clearly or more adequately or in conjunction with other questions which the Court feels should also be considered. Again, the Court, in determining whether the issue involved is of the required importance, may, and indeed perhaps should in some instances, consider whether the time is one for decision of the particular question. In other words, the occasion may well be regarded as an appropriate consideration in appraising the public importance of the issue presented. For example, a period such as we are now experiencing, when many congressmen, senators and other governmental officials are joining citizens and private organizations in witch hunts which gravely imperil civil liberties, may be thought to make doubly important issues of freedom of speech, self-incrimination and contempt of court. On the other hand, broad considerations of public interest and tolerance may lead more than five members of the Court to believe that long-range justice will be better served by delay in the determination of a particular issue of national concern. "Pertinent considerations of judicial policy here come into play. . . . Wise adjudication has its own time for ripening. ${ }^{38}$ During the past term, the Court reviewed several segre-

35. 338, U.S. 912,918 (1950).

36. Ibid.

37. See, for example, cases denied because the petition departed from the requirement of brevity or clarity, Tiger v. Lozier, 275 U.S. 496 (1927); or because the brief was inadequate, Zap v. United States, 326 U.S. 777 (1945) [but the Court subsequently changed its mind and its action and gave counsel a chance to try again. 326 U.S. 714 (1945) ].

38. Justice Frankfurter on denial of certiorari in Maryland v. Baltimore Radio Show, 338 U.S. 912, 918 (1950). 
gation cases of great importance. ${ }^{39}$ It will be interesting to observe the grants and denials in other segregation cases during the next few terms. And if the Court declines to consider such cases for some years, it may be a plausible explanation that the Court, like litigants, has its strategy.

As another consideration which might be thought to influence them, justices being what they are, the possible outcome of a review should be mentioned. A justice or, for that matter, six of them, might very properly vote for denial because persuaded that if the writ were granted, five or more justices might decide the issue wrongly. It is altogether understandable that a justice who has strong convictions about a case of public importance might prefer to have the decision of an inferior court stand rather than to have it authenticated in affirmance by the highest Court. Thus, although dissatisfied with the result below, he votes against review.

In some instances, however, it is almost impossible even to speculate as to the reasons for a denial of certiorari. A recent series of cases serves as an excellent illustrative example.

In November 1949, the Supreme Court was asked to review the Court of Appeals for the Third Circuit's decision in Johnson v. Dye. ${ }^{40}$ Johnson, an escaped Georgia convict apprehended in Pennsylvania, brought a petition for a writ of habeas corpus in a Pennsylvania state court. He alleged inter alia that he had been subjected to cruel and unusual punishment while under confinement in Georgia. The writ was discharged whereupon Johnson, before exhausting his state remedies, brought another petition in the Pennsylvania federal courts. The Third Circuit found his allegations to be correct and ordered his release, stating that in an extradition case the prisoner need not follow the usual requirement of exhausting state remedies before petitioning for habeas corpus in a federal court. ${ }^{41}$

The Supreme Court granted certiorari and reversed in a one sentence per curiam opinion ${ }^{42}$ which merely cited Ex parte Hawk. ${ }^{43}$ The Hawk case involved the failure of a prisoner in a Nebraska penitentiary under sentence of a Nebraska court to exhaust his state remedies before seeking habeas corpus in the federal system. The dis-

39. Sweatt v. Painter, 338 U.S. 865 (1950) (law school) ; McLauren v. Oklahoma State Regents, 70 Sup. Ct. 851 (1950) (graduate school) (both unanimous decisions, opinions by the Chief Justice); Henderson v. United States, 70 Sup. Ct. 843 (1950) (railroad dining cars).

40. 175 F.2d 250 (1949).

41. Judge O'Connell dissented, stating that the prisoner should be required to show that he would receive cruel and unusual punishment if returned to Georgia.

42. Dye v. Johnson, 338 U.S. 864 (1949).

43. 321 U.S. 114 (1944). 
tinction that the Third Circuit drew between extradition and nonextradition cases thus was ignored.

Later in the term, a petition for a writ of certiorari was filed from the decision of the Ohio Court of Appeals in Ex parte Quillian ${ }^{44}$ to the effect that the remedy of an escaped Georgia prisoner lay in the Georgia and not the Ohio courts. ${ }^{45}$ The Supreme Court, perhaps feeling that Johnson v. Dye settled the issue, denied the writ. ${ }^{46}$ Justice Douglas voiced the sole dissent.

In the meantime, however, two lower federal courts were wrestling with the problem of the application of the Dye ruling to the issue presented in Ex parte Quillian. They both of necessity looked back to the Hawk decision but came to different conclusions. The Second Circuit ${ }^{47}$ read Ex parte Hawk as applied to the Dye situation to mean that the prisoner had to exhaust his remedies in the courts of the state of apprehension before entering federal court. The District of Columbia Circuit, ${ }^{48}$ on the other hand, felt that the Supreme Court must have meant that Johnson had to pursue his remedy in Georgia and not in Pennsylvania. ${ }^{49}$ Petitions for writs of certiorari were filed from both decisions.

Reading Supreme Court Rule 38(5)b, set out supra, one might think that no two cases could better come within its scope. An ambiguous one sentence opinion of the Court had been interpreted in diametrically opposed ways by federal courts of appeals. And the problem involved was one which is continually confronting courts in habeas corpus proceedings arising out of the apprehension in another

44. 89 N.E.2d 493, appeal dismissed by the Ohio Supreme Court, 89 N.E.2d 494 (1949).

45. The court relied upon Drew v. Thaw, 235 U.S. 432, in which Mr. Justice Holmes stated that the Constitution "peremptorily requires that upon proper demand the person charged shall be delivered up to be removed to the state having jurisdiction of the crime." The Third Circuit decision in Johnson $v$. Dye, rendered a month before, was not mentioned.

46. 339 U.S. 945 (1950).

47. United States ex rel. Jackson v. Ruthazer, 181 F.2d 588 (1950). Petitioner had exhausted his remedies in the state courts of New York, where he had been apprehended. On this basis, the Second Circuit held Johnson v. Dye distinguishable. Had the court given the Dye ruling the alternative meaning, the two cases could not have been so distinguished since neither Johnson or Jackson had instituted proceedings in Georgia.

48. Johnson v. Matthews, 182 F.2d 677 (1950).

49. Said Judge Prettyman: "If the Supreme Court, in Johnson v. Dye, mean that the petitioner must exhaust his remedies in the Pennsylvania courts (where he was being held for extradition only), it meant that those courts had jurisdiction to entertain, and so to grant, his petition on the grounds he alleged. That would have been a revolutionary reversal of all the cases on the subject, and we have serious doubts that the Court intended to accomplish that result without argument and without opinion. Rather it seems more reasonable that the Court meant, by citing Ex parte Hawk, to tell the petitioner to apply first to the state courts of Georgia which had jurisdiction over the executive officials against whom he was complaining." Id. at 683 n. 7. Judge Bazelon dissented, following the Second Circuit interpretation. 
state of escaped convicts. ${ }^{50}$ But the Supreme Court apparently decided to leave the issue in its present confused state. Certiorari was denied in both cases. ${ }^{51}$ To look for a reason is futile. ${ }^{52}$

But it is not only the impossibility of learning why the Supreme Court denies certiorari that takes knowledge of many of these cases beyond practical reach by the bar. The mystery is intensified by other factors. In the first place, the cases on the miscellaneous docket are, for the most part, almost impossible to identify much less examine without weeks of painstaking work at the Supreme Court building in Washington. The Clerk does not even have a list of them compiled. The published reports of the Court contain the docket numbers and the names of the parties. There is no citation to the case below; in many of them, there is not and never was a citation. In most, the jurisdiction involved is revealed only by such a circumstance as the name of the respondent in a habeas corpus proceeding where the petitioner is a prisoner and the respondent a well known warden. In cases where there is a citation, it can usually be discovered only by a tedious examination in the dark of the many Tables of Cases in the various federal and state jurisdictions which, of course, presents an enormous task where 436 cases are involved.

Even the appellate docket sometimes presents problems which tend to make the curtain difficult to penetrate. For the 1949 term, the authors have been unable to find 37 cases which were reported in Law Week as among those in which certiorari was denied; and in at least 18 others, no opinion was rendered in any court below. Since the Supreme Court rendered none, there is often no practical way of finding out what officially was involved (although Law Week may give a brief summary of the facts), to say nothing of obtaining facts on which to base any kind of critical judgment. ${ }^{53}$

50. At least one district court has dealt with the question in 1950. Application of Middlebrooks, 88 F. Supp. 943 (S.D. Cal. 1950). The court specifically held, in discharging the prisoner, that he need not seek his remedy in Georgia. Johnson v. Dye was cited as authority.

51. Jackson v. Ruthazer, cert. denied, 339 U.S. 980, (1950); Johnson v. Matthews, cert. denied, 19 U.S.L. WEEK 3098 (October 9, 1950).

52. Unquestionably the grounds for granting certiorari were stronger in the Matthews case. The Ruthazer decision went against petitioner because he had had a full and fair hearing in the New York courts. The petition for certiorari therefore did not raise the jurisdictional issue as it might have had the prisoner been discharged on the merits and the respondent warden brought the petition. Regardless of Jackson's ultimate fate, however, the Ruthazer interpretation of Johnson $v$. Dye stands and should have been accepted or rejected. The Mattheres case presented the perfect opportunity. The District of Columbia Circuits' interpretation was squarely presented as an issue and the Court was presumably aware of the contrary reasoning of the Second Circuit.

53. For example, the authors received the following letter from the Clerk of the Supreme Court of California in response to an inquiry about the case of Taylor v. 
Notwithstanding the difficulties of a comprehensive survey of the cases which the Supreme Court declined to consider on their merits, a limited view can be obtained of the entire situation and a fairly extensive one of the cases which were placed on the appellate docket. Some of the results are interesting and presumably have some significance regardless of the silence with which the Court envelopes them.

\section{Grist of the Certiorari Mill}

Of the 597 cases on the appellate docket in which petitions for certiorari were denied, the authors were unable to locate 37 . This reduced the number to 560 . When the 78 companion cases are subtracted, there are 482 left. Of these there was no opinion below filed in 18 . This leaves 464. An examination of the opinion of the inferior courts in these cases showed 64 which the authors classified as presenting an issue of national importance and thus such that a reasonable person might suppose deserved review by the highest court in the land. One or more justices dissented in $20^{54}$ cases. $^{55}$ In 78 cases there were dissenting opinions in the inferior courts, in 17 of which more than one justice joined. Thirty-three cases were regarded as of sufficient importance to call for comments in law reviews up to June, 1950, some of them in a half dozen different journals.

A word of explanation is necessary in connection with the choice of cases characterized as "important." If the authors regarded a case as presenting a close issue of national policy, it was included, notwithstanding a prior Supreme Court decision consistent with the position of the lower court, particularly if the authors disagreed, on the merits, with the precedent. Thus, cases are included in this group even though they may not come, literally, within the wording of Rule 38. As a

Municipal Court of Los Angeles, in which the Supreme Court of the United States denied a petition for a writ of certiorari.

"Dear Mr. Harper:

"Our records disclose that the District Court of Appeal of the Second Appellate District on April 6,1949, denied a petition for writ of certiorari and mandate in the above proceeding, without opinion.

"This court on June 2, 1949, denied a hearing in the matter, without opinion. Consequently, no opinion having been filed in either court, I am unable to furnish you with the requested citation.

"Very truly yours,

(Signed) William I. Sullivan Clerk of Supreme Court"

At this point the authors' labors ended so far as concerned Taylor v. Municipal Court of Los Angeles.

54. Dissents were also noted in 5 cases placed on the miscellaneous dockets.

55. Justice Black dissented in all 20 cases. Justice Douglas who was absent for most of the term dissented in 6 , Justice Reed in 3, Justice Jackson in 1, and Justice Burton in 1 . In 2 cases there were 3 dissenting justices, in 7 cases, 2. 
national policy-forming body of last resort, the function of the Court is something more than merely matching case against precedent. As every high school student knows, the Court throughout its historyincluding the not too remote history-has vacillated on controversial issues of policy. In the authors' view, this is not necessarily undesirable even when the vacillation is the result of conflicting political pressures. Accordingly, a question may be of sufficient "importance" to justify Supreme Court review although decided by a lower court in precise conformity with decisions of the Supreme Court.

Moreover, it is the thesis of this article that the influence of the Supreme Court in our system of government cannot be accurately appraised by a consideration only of the cases which it reviews and decides by written opinion. The cases which it declines to review and pass on may be of equal or greater significance. And the fact that the latter are so difficult to appraise, if not, indeed, to identify, may be thought to make the matter even more important. In every case selected as "important," the question for the authors has not only been whether the case came within the announced rule of the Court on certiorari but whether it presented an issue of such importance to the nation as to deserve consideration or reconsideration in these times.

The breakdown of the 64 "important" cases, according to the type of question involved, discloses the largest group to raise questions of civil rights other than those involved in problems of citizenship or aliens. Of the 36 cases classified in this group, 22 were regarded as "important." Of the 7 cases involving citizenship or rights of aliens 5 were also so classified. Thus, broad issues of civil liberties, the great achievement of democratic society, were left unresolved in 27 out of the 43 cases in these two groups. Of 17 labor cases, 4 were thought by the authors to be "important" while 5 of 9 cases involving conflict of laws questions were so classified. Of the 127 cases classified as "miscellaneous," raising a variety of questions from interpretation of treaties to questions under the Tucker Act, 10 were such that reasonable lawyers might regard the issues as important. On the other hand, of 44 cases involving taxation only 4 were so regarded; 3 of 25 patent or trade mark cases; 1 each of the 54 cases depending on diversity jurisdiction, 27 cases involving questions of federal jurisdiction and procedure, 31 cases involving questions of federal criminal law other than civil rights, 19 bankruptcy cases, 18 admiralty cases and 7 anti-trust cases. Of 6 cases involving veterans or military questions, 6 involving the review of administrative proceedings and 8 involving rent control or O. P. A. questions, none was classified as "important." 


\section{A "Close-Up" of Some Denials}

The authors, in selecting cases for comment, have designedly picked those which in their judgment raise the most controversial problems of broad national interest. There is no inference at all that the remaining cases classified as "important" are of equal significance although they were thought to be of sufficient interest to justify inclusion in the "important" group. Since the largest group of "important" cases which the Court declined to review involved civil liberties, naturally the largest proportion to which special attention will be called is from this group.

Take Lapides v. Clark $^{56}$ decided by the Court of Appeals for the District of Columbia, Judge Edgerton dissenting, commented on in three law reviews. ${ }^{57}$ A brief amicus was filed in the Court of Appeals by the American Jewish Committee. Lapides and his wife, originally Roumanian, had become naturalized in the United States and enjoyed the advantages of American citizenship for 20 years. In 1934, the Lapides with their son, a native born citizen, went to Palestine. Lapides did not return to the United States until July 3, 1947, where he spent the 4th of July on Ellis Island. Indeed, he is theoretically there yet. Actually, he is at liberty under a bond and the Immigration service has suspended proceedings for exclusion ${ }^{58}$ because of a bill pending in the Senate to legalize his entry. Presumably, since Knauff v. United States ${ }^{59}$ the Service may not proceed farther so long as such a bill is pending. In the meantime, the Lapides boy, still a minor, has returned to his native land to complete his education. The same statute $^{60}$ which excluded Lapides, of course, is also applicable to his wife who, unable to obtain any kind of travel document, has got no closer to the United States than Paris. ${ }^{61}$ The unhappy Lapides are now a

56. 176 F.2d 619 (D.C. Cir.), cert. denied, 338 U.S. 861 (1949).

57. 63 HARv. L. Rev. 885 (1950); 59 YALE L.J. 139 (1950); 38 Geo. L.J. 137 (1950). For detailed discussion of the issues involved see Roche, Loss of American Nationality, The Development of Statutory Expatriation, 99 U. oF PA. L. REv. 25 (1950).

58. The Service had rejected Lapides' claim to a right to entry based on the evidence of his naturalization certificate, on the ground that he had been expatriated by the operation of Section 404 of the Nationality Act of 1940 as amended (8 U.S.C. $\$ \S 804,809$ ) [1946], the pertinent part of which provides that: "A person who has become a national by naturalization shall lose his nationality by: . . ( (c) Residing continuously for five years in any other foreign state, except as provided in Section 806 hereof." The exceptions are inapplicable to Lapides.

59. 181 F.2d 839 (2d Cir. 1950).

60. Silpra note 58.

61. The State Department's policy of cooperation with the Justice Department had led American consuls in Tel Aviv and Paris to refuse Mrs. Lapides a visitor's visa because she would not be a bona fide visitor but presumably would, once here, indulge in the same strategy as her husband if Senator Gillette continued to be cooperative. 
broken family, with the Lapides son in the position where he is forced to make the miserable choice of giving up his country or his mother.

The legal question raised by Lapides $v$. Clark was the constitutionality of Section 404 of the Nationality Act of 1940. Lapides contended that Congress could not confer citizenship with a condition subsequent attached ${ }^{62}$ and thus create a citizenship, second class; that the discrimination between naturalized citizenship and natural born citizenship is unconstitutional. Indeed, the "condition subsequent" was in the nature of a retroactive one in this case, since Section 404 was enacted long after the Lapides had been naturalized and even after they had left the country. The Act of $1907^{63}$ had been interpreted as providing only for loss of diplomatic protection by a naturalized citizen who had lived abroad for 5 years, in a country not of his origin. ${ }^{64}$

The American Jewish Committee in its brief stressed the point that the statute was sufficiently broad to include both voluntary and involuntary residence abroad and the fact that one type of involuntary residence, ill health, ${ }^{65}$ was excepted from the sweeping language of Section 404 supports this construction. It further pointed out that the only case in which the Supreme Court has upheld a conclusive presumption of expatriation involved what was clearly a voluntary act-marriage by a female national to an alien. ${ }^{66}$ The government contended that Lapides' residence abroad was voluntary but he was never given an opportunity to show the contrary since the trial court dismissed his petition.

Judge Edgerton based his dissent on the broad ground that discrimination between naturalized and other citizens is unconstitutional. "A 'rule of naturalization," he said, "regulates eligibility and procedure for becoming a citizen. It increases the number of citizens, but does not divide them into classes. By authorizing Congress to prescribe who may become naturalized and how, the Constitution does not authorize it to deprive citizens either at or after naturalization of liberties that other citizens enjoy." ${ }^{87}$

62. "American citizenship is not a right granted on a condition subsequent. . ." Justice Murphy concurring in Baumgartner v. United States, 322 U.S. 665,679 (1944).

63. 34 Stat. 1228 (1907).

64. 28 OP. ATT'y GEN. 504, and see United States v. Gay, 264 U.S. 353 (1924); Nurge v. Miller, 286 Fed. 982 (1923).

Before the 1940 amendment to the Nationality Act, a Cabinet Committee of Advisors rejected a more severe rule for naturalized citizens residing abroad for more than 5 years in a country not of origin, but recommended automatic expatriation if the residence was in the country of origin. See Hearings before Committee on Immigration and Naturalization on H.R. 6127 superseded by H.R. 9980, 76th Cong., 1st Sess. 493,495 (1932). The reason for the distinction is fairly obvious and is explained therein by the Committee.

65. Section 406, 54 Stat. 1170 (1940), as amended, 8 U.S.C. § 806 (1946).

66. MacKenzie v. Hare, 239 U.S. 299 (1915).

67. 176 F.2d 619, 622 (1949). 
It is obvious that the question raised in the Lapides case is an important one. Loss of citizenship is a terrible penalty. Justice Rutledge in Klapprott $v$. United States, ${ }^{68}$ said in a concurring opinion:

"To lay upon the citizen the punishment of exile for committing murder, or even treason, is a penalty thus far unknown to our law and at most but doubtfully within Congress' power. U. S. Const. Amend. VIII. Yet by the devise or label of a civil suit, carried forward with none of the safeguards of criminal procedure provided by the Bill of Rights, this most comprehensive and basic right of all, so it has been held, can be taken away and in its wake may follow the most cruel penalty of banishment."

If it is to be done, such punishment should be imposed only after a full hearing and trial of all the important facts. Lapides not only failed to get his day in the Supreme Court, but, on at least one of the vital factual issues, it seems that he got no day in court at all.

Although Lapides' case involved only the grief of one man's family, troubles of this nature are not confined to these three people. Under the operation of Section 404, a substantial number of Americans have lost their citizenship. ${ }^{69}$ Why did the Supreme Court decline to review a question of such broad national interest? We are told that it is useless even to speculate. ${ }^{70}$

In Trumbo v. United States and Lawson $v$. United States ${ }^{71}$ the Court of Appeals for the District of Columbia affirmed convictions for contempt of the Committee on Un-American Activities of the House of Representatives. The Supreme Court denied certiorari and thus sealed the fate of the "Hollywood Ten." Defendants had refused to say whether they were or ever had been members of the Communist Party, contending that the First Amendment to the Constitution of the United

68. 335 U.S. 601 (1949).

69. Involuntary Loss of Anerican Citizenship, Report of the SPECral Comarrttee on Expatriations National Council on Naturalization and Citizenship 16 (1947).

70. Other cases in which the Court declined to review problems involving deportation or citizenship are United States v. Eichenlaub, 180 F.2d 314 (2d Cir.), cert. destied, 70 Sup. Ct. 1028 (1950) ; People ex rel. Choolokian v. Mission of The Immaculate Virgin, 300 N.Y. 437, 88 N.E.2d 302 (1949), cert. denied, 339 U.S. 912 (1950); Schoeps v. Carmichael, 177 F.2d 391 (9th Cir. 1949), cert. denied, 339 U.S. 914 (1950); Gregoire v. Biddle, 177 F.2d 579 (2d Cir. 1949), cert. denied, 339 U.S.949 (1950), as to which, see 38 GEo. L.J. 327 (1949).

On a previous petition, the Court had granted certiorari in another Eichenlaub litigation and affirmed a lower court decision that petitioner could be deported under a statute which made the commission of certain crimes by an alien a deportable ground, although petitioner, since denaturalized, was a naturalized citizen at the time of the offense. United States ex rel. Eichenlaub v. Shaughnessy, 338 U.S. 521 (1950), Justices Frankfurter, Black and Jackson dissenting. See the comment on this case by Frank, The United States Supreme Court, 1949-1950, 18 U. OF CrrI. LAW REv. 1, 23 (1950).

71. 176 F.2d 49 (D.C. Cir. 1949), cert. denied, 339 U.S. 434 (1950). 
States, guaranteeing Freedom of Speech, also guaranteed them freedom of silence. They further contended that the question had no legitimate relation to any. Constitutional function of Congress and thus was in excess of the Committee's authority. The Court of Appeals held that the Committee was properly constituted and that the investigation of communist infiltration in the moving picture industry was a proper subject for Congressional inquiry. When legislating to arrest what it believes to be a threat to the national security or welfare, Congress may abridge either the right to remain silent or the right of free speech and may require an individual to make a statement believed necessary to arrest an anticipated evil. It can hardly be doubted that the issues raised are important in a free country. Dissents were "noted" by Justices Black and Douglas. It is an easy guess as to how Justices Murphy and Rutledge would have voted.

In Marshall v. United States, ${ }^{72}$ the Court of Appeals for the District of Columbia affirmed the conviction of the chairman of the "National Federation for Constitutional Liberties" for contempt of the same House Committee when he refused to produce records and documents pursuant to a Committee subpoena. Prior to trial, defendant moved to dismiss on the grounds that the resolution creating the Committee was unconstitutional. The Court of Appeals held that the constitutionality of the Committee had been established by the decision in Barsky v. United States, ${ }^{73}$ in which the Supreme Court denied certiorary at the 1947 term. ${ }^{74}$ Only Justice Black avowed his dissent to the denial of certiorari in Marshall's case.

Citations for contempt of Congressional Committees may raise further problems for the Court. The "Hollywood Ten" and other cases raised the questions whether the House Committee on Un-American Activities is a "constitutional" committee and whether the First Amendment protects "freedom of silence." The Court of Appeals for the Second Circuit has now affirmed Judge Medina's decision that the ten Communist leaders are guilty of violation of the Smith Act ${ }^{75}$ which makes criminal, conspiracies to advocate or advocacy of the overthrow of the government by force. Under the decision, membership in the Communist Party may be a crime. ${ }^{76}$ The Supreme Court will have the

72. 176 F.2d 473 (D.C. Cir. 1949), cert. denied, 389 U.S. 434 (1950).

73. 167 F.2d 241 (D.C. Cir. 1948).

74. 334 U.S. 843 (1948).

75. 183 F.2d 201 (2d Cir. 1950).

76. It seems clear from Judge Hand's opinion that simply because the validity of the Smith Act was upheld in this case the court does not hold that membership in the Communist Party is necessarily unlawful at all times under any and all circumstances under the Act. The Court held "the Smith Act to be constitutional, as the judge construed it; and that evidence supported the verdict of the jury." 183 F.2d 201, 215 (2d Cir. 1950). 
task of determining whether it will review the holding of the Second Circuit on the constitutionality of the Smith Act and the legality of the convictions thereunder. If it declines to review, or if, reviewing, it affirms, it may then have the problem whether it will review contempt convictions of witnesses who refuse to answer the "are you now or have you ever been" question on the grounds of self-incrimination. ${ }^{77}$ The issue is "important." 78

The work which the Court did in respect to the Nation's Number One civil rights problem, segregation, should be considered in relation to the work it refused to do in connection with the same problem. The Court wound up the term in a blaze of democratic glory with unanimous decisions written by the Chief Justice. ${ }^{70}$ But this is only a part of the story. At least two important aspects of the segregation issue were avoided.

77. In Doran v. United States, 181 F.2d 489 (9th Cir. 1950), a civil contempt proceeding, the Court of Appeals for the 9th Circuit by a 4-3 vote held that witnesses before a federal grand jury could refuse to answer questions about the organization and membership of the communist party on the ground that the answers would incriminate them. The court held similarly in Alexander v. United States, 181 F.2d 480 (9th Cir. 1950).

However, in Rogers v. United States and Blau v. United States, 180 F.2d 103 (10th Cir. 1950), a Federal grand jury investigation of loyalty of employees of the government, Rogers and Blau refused to answer any questions showing membership in, connection with or knowledge of activities of the Communist Party on the grounds that it would incriminate them in light of the indictment and trial of the party leaders in New York for violation of the Smith Act. Rogers and Blau then were brought before the district judge, Blau without, Rogers with a formal presentment. They still refused to answer. They were found guilty of contempt and the conviction was affirmed by the Court of Appeals for the Tenth Circuit which stated that membership in the Communist Party was not [yet] a criminal offense. In the Blau case, certiorari was granted, 70 Sup. Ct. 979 (1950). In the Rogers case it was denied, 70 Sup. Ct. 999 (1950). No difference is suggested between these cases and the case of the similar question raised by refusal to testify before a Congressional committee. The respective spouses of the above mentioned litigants had previously gone through the same contempt proceedings, 179 F.2d 559 (10th Cir. 1950). The Supreme Court granted certiorari in both cases. 70 Sup. Ct. 978 (1950).

78. The Court during the past term, refused to review United States v. Rosen, 174 F.2d 187 (2d Cir.), cert. deried, 338 U.S. 851 (1949), in which the Court of Appeals for the Second Circuit had reversed a conviction for contempt when the accused had declined to answer questions before a grand jury pertaining to the ownership of a Ford car which Alger Hiss had claimed he gave to Whittaker Chambers. Grounds for refusal were self-incrimination. But it also declined to review Kamp v. United States, 176 F.2d 618 (D.C. Cir. 1948), cert. dertied, 70 Sup. Ct. 977 (1950), in which the Court of Appeals for the District of Columbia affirmed a conviction of "willfully making default" in violation of an Act of Congress (2 U.S.C. \$ 192) when defendant had failed to produce records before a Congressional Committee after he had been served with a document described in the indictment as a subpoena, directing the Sergeant at Arms to summon defendant to testify and commanding the officer rather than the witness to produce the records (Constitutional Education League, Inc.). The trial court overruled a demurrer to the indictment and excluded testimony offered by the accused to show lack of willful intent to make default.

United States v. Green, 176 F.2d 169 (1949), United States v. Winston, and United States v. Hall, 176 F.2d 163 (1949), all in the Court of Appeals for the Second Circuit affirmed contempt convictions by Judge Medina growing out of the famous "Communist Trial" in Foley Square. The Supreme Court denied certiorari in all three cases, 338 U.S. 851 (1950), Justice Black alone "noting" his dissent.

79. See cases cited in note 39 supra. 
In the Stuyvesant Tozen case ${ }^{80}$ the Court declined to review the issue of segregation in housing. A Negro war veteran brought an action to enjoin a private corporation ${ }^{81}$ from denying him an apartment on account of his color. The corporation was the beneficiary of public funds in the sense that it received tax exemption privileges in accordance with a plan approved by the city planning commission and the board of estimates of the City of New York. The plaintiff lost in the New York Court of Appeals by a 4 to 3 decision. ${ }^{82}$ Justices Black and Douglas "noted" dissents to the denial of certiorari. The case was "important" by anybody's standard.

Probably nobody would deny that Negroes like to play tennis. And if they want to play tennis with white friends on public courts, it is at least a fair question whether they should have such privileges in a democratic country. But they can't have them in Maryland. ${ }^{83}$ And the Supreme Court declined, for some reason or other, to face this issue.

When one stops to consider the number of American citizens whose lives are profoundly affected by segregation in education at the

80. Dorsey v. Stuyvesant Town Corp., 299 N.Y. 512 (1949), cert. denied, 70 Sup. Ct. 1019 (1950) commented on in 98 U. OF PA. L. Rev. 247 (1949); 35 CorNell L.Q. 399 (1949) ; 35 VA. L. Rev. 917 (1949); 38 Geo. L.J. 309 (1950); 25 Notre Dame Law 146 (1950) ; 16 Brooklyn L. Rev. 110 (1950); 23 Tearple L. Rev. 209 (1949); 4 Miami L. Rev. 102 (1950).

81. Stuyvesant Town is a subsidiary of the Metropolitan Life Ins. Co. and was organized under the New York Redevelopment Law as a $\$ 90,000,000$ corporation which bought 18 city blocks after the City of New York had condemned the property. The Town converted the area into an 8400 apartment low rental housing project.

82. The court declined to follow the growing authority that private organizations whose functions are surcharged with high voltage public interest because they affect interests of large numbers of people (see Marsh v. Alabama, 326 U.S. 501, 506 (1945). The condemnation proceedings unhoused some 3000 families. Carson, Urban Redevelopment Legislation, American City, Nov. 1946, p. 93. Of course, the decision will affect thousands more in similar areas) and whose efforts are assisted or encouraged by state action, may not discriminate on account of race or color when the states themselves are forbidden by the Constitution to do so. See Steele v. Louisville and Nashville R. Co., 323 U.S. 192 (1944) (discrimination by labor union having statutory bargaining powers) ; Smith v. Alwright, 321 U.S. 649 (1944) (racial discrimination by "private" political party); Marsh v. Alabama, 326 U.S. 501 (1945) (prohibition of distribution of religious literature on streets of "privately owned" town). See comments, 98 U. of PA. L. REv. 247 (1949); 35 CoRNELL L.Q. 399 (1950).

83. Winkler v. State, 69 A.2d 674 (1949) (a 5 to 1 decision), cert. denied, 339 U.S. 919 (1950). The Baltimore Park Board had a policy of segregation on the municipal tennis courts. Winkler and others, desiring to test this policy, obtained a permit and started an interracial game of tennis. Leaflets had been distributed and a good sized crowd was in attendance. The police requested the game be discontinued and when it wasn't arrests were made accompanied by some disorder, though everything had been previously peaceful. Winkler and his companions were arrested for violating the rules of the Board and for conspiring to disturb the peace and were brought to trial on the latter charge. Their conviction was affirmed by the Maryland Court of Appeals over the vigorous dissent of one of its members who felt the defendants were convicted of exercising their constitutional rights of freedom of speech and freedom to play interracial tennis on a public court upon compliance with all formal requirements, in the absence of any valid segregation law, rule or regulation. $C f$. Taylor v. City of Birmingham, 45 So. 2d 53 (C. A. Ala. 1950), cert. denied, 19 U.S.L. WEEK 3097 (U.S. Oct. 9, 1950). 
graduate and professional level on the one hand, and in housing and recreation on the other, ${ }^{84}$ he gets a perspective on the work which the Supreme Court did and the work which it didn't do during the past term.

The Court denied certiorari in a number of other cases involving assorted questions of civil rights, some no doubt decided in a manner which could be regarded as consistent with prior decisions of the Court and some which can hardly escape appraisal as an extension or contraction of such decisions. Still others gave the Court an opportunity, if it had wanted one, to review past decisions, re-evaluate the policies involved and resettle or unsettle important issues.

A Connecticut case ${ }^{85}$ involved conviction of murder after accused had been confined for 7 days in the State Police barracks on a coroner's warrant. The trial court found that accused's confession after such confinement was admissible since it had not been obtained by physical violence. The Court of Errors and Appeals affirmed, holding that a confession thus "voluntarily" made was admissible and would not become otherwise because made during an illegal detention unless the detention is shown to be causally connected with the confession.

In an Illinois case, ${ }^{86}$ an action had been instituted to review orders of a municipal civil service commission discharging two policemen because they had refused to sign immunity waivers in advance of testifying before a grand jury concerning matters pertaining to their occupation. The Appellate Court affirmed the Commission's orders on the ground that a police officer by reason of his special status, duties and responsibilities may not invoke the constitutional privilege against selfincrimination in matters touching upon his occupation without being guilty of a breach of duty by refusal to testify.

In State v. $\mathrm{Nagel}^{87}$ there had been a conviction for contributing to the delinquency of a minor, the daughter of the county judge before whom the accused was arraigned. After setting bail, excusing jurors and ordering additional jurors to be summoned, the judge disqualified himself and testified as a witness for the prosecution. The judge had been the complaining witness. The trial court denied defendant's motion for a change of venue. The Oregon Supreme Court affirmed.

84. It is recognized that Negroes suffer from inadequate housing more than any other racial group in the United States. See Clark and PerLman, PrEJUdice and Property, 12 et seq. (1948).

85. State v. Buteau, 68 A.2d 681 (1949), cert. denied, 339 U.S. 903 (1950).

86. Drury v. Hurley, 339 IIl. App. 33, 54 (1949) (two cases), cert. denied, 70 Sup. Ct. 1027 (1950).

87. 185 Ore. 486, 202 P.2d 640, cert. denied, 338 U.S. 818 (1949). 
In a Michigan case, ${ }^{88}$ the Supreme Court of that State, without opinion, denied an application for leave to appeal the conviction for indecent exposure of a member of a nudist group who had been arrested without a warrant by an officer who, without permission, entered private grounds which had been rented by the "club" for sunbathing.

Four cases ${ }^{89}$ involved conviction for violations of provisions of the Selective Service Act based on religious grounds. Three of the four concerned refused to register or submit to induction. The fourth ${ }^{90}$ involved Section $12 \mathrm{a}$ of the Act making it an offense knowingly to counsel another to refuse or evade registration or service in the armed forces. The defendant counseled his stepson to refuse to register insofar as the boy's objections were based on religious grounds. For this he was convicted, even though the boy had in fact rejected the counsel.

Two cases involved restrictions imposed by professional societies on persons who have met statutory qualifications for the practice of their profession. In an Indiana case, ${ }^{91}$ a physician had been excluded from the use of a hospital under a rule requiring practitioners in the hospital to be members of the active resident staff which in turn was conditioned on membership in the county medical society. An additional rule required a surgeon practising in the hospital who was not a member of the staff to have served as an intern for one year in an approved hospital or to have had three years of surgical training. The Indiana Court held that the hospital might not require practitioners, as a prerequisite for the use of its facilities, to become members of its resident staff inasmuch as this amounted to a preference in favor of members of the medical society and a discrimination against those physicians who, by choice or otherwise, are not members of it. It upheld, however, the rule affecting surgeons.

In a Pennsylvania case, ${ }^{82}$ a lawyer challenged the constitutionality of a local rule of court requiring attorneys desiring to practice in Montgomery county to declare that they would open and maintain their principal office in that county. This rule, the purpose of which

88. People v. Church, 18 U.S. LAw WeEk 3201 (Mich. 1949), cert. denied, 70 Sup. Ct. 997 (1950).

89. United States v. Henderson, 180 F.2d 711 (7th Cir.), cert. denied, 70 Sup. Ct. 997 (1950); United States v. Wixom (C.A. 7th Cir.), cert. denied, 70 Sup. Ct. 1030 (1950), in which no opinion was rendered, the court deciding the case on the authority of the Henderson case; United States v. Mansavage, 178 F.2d 812 (7th Cir. 1949), cert. denied, 339 U.S. 931 (1950) ; Warren v. United States, 177 F.2d 596 (10th Cir. 1949), cert. denied, 338 U.S. 947 (1950).

90. Warren v. United States, supra note 89.

831 (1949).

91. Hamilton County Hospital v. Andrews, 84 N.E.2d 469, cert. denied, 338 U.S.

92. Christy v. Conover, 362 Pa. 347, cert. denied, 338 U.S. 869 (1949). 
is pretty obvious, was upheld as a "reasonable" exercise of the power of government.

Two cases in which the Supreme Court denied certiorari petitions involved political processes, ${ }^{93}$ another the right to attend a tax supported educational institution, ${ }^{94}$ and still another the privilege of public officers. ${ }^{95}$ The Arkansas Supreme Court upheld a conviction for violation of a statute forbidding the distribution of any sample ballot other than those ordered for use in the election, for the purpose of instructing voters how to vote. The defendant had spoken at a political meeting at which prohibited ballots had been distributed and at which he advised those present how to vote and for whom to vote. ${ }^{96}$ The Georgia Supreme Court ${ }^{97}$ affirmed a decision upholding a statute setting up a new registration system under which all persons, as prerequisite to voting in state and federal elections, must be able to read intelligently and write legibly selected portions of the state or federal constitution, or must appear before before the Board of Registrars and "correctly" answer 10 out of 30 questions propounded by the Board dealing with civics and government. ${ }^{98}$ The Supreme Court of Michigan refused to require a State College to reinstate a student who was expelled because, as a member of an unrecognized student organization, he had arranged an off-campus meeting at which an indicted member of the Communist party spoke. ${ }^{98}$ The Court of Appeals for the Second Circuit held that an action for false imprisonment would not lie against the Attorney General, the Director of the Enemy Alien Control unit of the Department of Justice and the District Director of Immigration at Ellis Island, even though they acted maliciously so long as they purported to act in the line of duty, ${ }^{100}$ a decision pushing the absolute privilege of members of the bureaucracy exercising quasi-judicial powers about as far as it can be pushed. ${ }^{101}$

93. Branton v. State, 214 Ark. 861,218 S.W.2d 698, cert. denied, 338 U.S. 869 (1949); Franklin v. Harper, 55 S.E.2d 221 (Ga. 1949), cert. denied, 70 Sup. Ct. 804 (1950).

94. Zarichny v. State Board of Agriculture, 18 U.S. LAW WEEK 3014 (Mich. 1949), cert. denied, 70 Sup. Ct. 56 (1949).

95. Gregoire v. Biddle, 177 F.2d 579 (2d Cir. 1949), noted in 38 GEo. L. Rev. 327 (1950).

96. Branton v. Arkansas, supra note 93.

97. Franklin v. Harper, supra note 93.

98. Two of the questions: who is the Chief Justice of the Georgia Supreme Court?; who succeeds the President if he dies in office? The contention was made that 1,200,000 persons were diseniranchised by the operation of this system.

99. Zarichny v. State Board of Agriculture, supra note 94.

100. Gregoire v. Biddle, supra note 95.

101. The absolute privilege applies to judges of courts of record (Bradley v. Fisher, 13 Wall. 335 (1871)) and, by some cases, to petty judicial tribunals. Cooke v. Bangs, 31 Fed. 640 (1887). It has been applied to protect high executive officers in policy forming positions (Spaulding v. Villas, 161 U.S. 483 (1895) (Postmaster General); Glass v. Ickes, 117 F.2d 273 (D.C. Cir. 1940) (Secretary of the Interior), and to soine 
The past term denials also included a group of Conflict of Laws cases some of which presented knotty problems under the Constitution and laws of the United States. The Missouri Supreme Court had held that the question whether a petitioner was entitled to a decree of equitable adoption in order to establish her claim to Iowa assets of an alleged adoptive relative should be determined under the laws of Missouri where a contract to adopt was entered into and which was presumably the domicile of the parties thereto. It further had held that the petitioner was not the adopted child of her deceased uncle since the statutory conditions to the status of adoption had not been met, thus denying the petitioner's prayer for relief. It had been contended that full faith and credit to the law of Iowa on the issue of equitable adoption was required in so far as it concerned the descent and distribution of Iowa property including both land and personalty. ${ }^{102}$ No obvious constitutional issue leaps to the eye although the case suggests complicated problems of qualification which conceivably might affect the determination of the applicability of the Full Faith and Credit clause. There may be further questions as to the effect of the decree on the petitioner's rights in Iowa although such questions are not raised by the case itself.

Moloney v. Moloney ${ }^{103}$ presented another of those distressing domestic tangles in which the children are the pawns of conflict between spouses and turn out to be the chief victims of a broken family. A father filed a petition for a writ of habeas corpus in Kansas to obtain custody of his minor children under a 34 day old Missouri decree awarding him custody. By a 5 to 2 decision the Kansas Supreme Court affirmed a decree denying the writ and awarding custody to the mother on the ground of "changed conditions" brought about during the period intervening between the two decrees. Because the Supreme Court, in its last sally at this delicate problem, ${ }^{104}$ left so many questions unanswered, it is perhaps understandable that it chose not to review the case. Perhaps there are no satisfactory solutions to such problems.

Other domestic issues were avoided by the denials in Walsh $v$. Walsh ${ }^{105}$ and United States Nat'l Bank of Denver v. Bartgos, ${ }^{106}$ another 5 to 2 decision in the State court. In the Walsh case, plaintiff had sought to have vacated a decree of divorce rendered in Louisiana in

lower executive or administrative officials. Brown v. Rudolph, 25 F.2d 540 (D.C. Cir. 1928) (commissioners of the District of Columbia). In Yaselli v. Goff, 275 U.S. 503 (1927) the Supreme Court held that the absolute immunity protected a special assistant to the Attorney General. By the Gregoire case, it now goes down the hierarchy to include the District Director of Immigration at Ellis Island.

102. Menees v. Cowgill, 223 S.W.2d 412, cert. denied, 338 U.S. 949 (1949).

103. 167 Kans. 444, cert. denied, 338 U.S. 903 (1949).

104. People of State of New York ex rel. Halvey v. Halvey, 330 U.S. 610 (1947).

105. 215 La. 1099, 42 So. 2d 860 (1949), cert. deried, 339 U.S. 914 (1950).

106. 210 P.2d 600 (Colo. 1949), cert denied, 338 U.S. 955 (1950). 
1944 by her husband, since deceased. The decree had been granted on allegations that the parties had been separated for more than two years and that the husband had established his residence in Louisiana after being transferred to a military base there in 1932. The "widow," resident of the District of Columbia, alleged that she had not received notice of the divorce proceedings, that the Louisiana court had no jurisdiction since her husband had not acquired a Louisiana domicile. On the basis of conflicting evidence the trial court vacated the divorce decree, but the Louisiana Supreme Court reversed on the grounds that the decree was presumptively valid and that the plaintiff had the burden of showing its invalidity. The court ignored the questions under $M c$ Donald v. Maybee ${ }^{107}$ raised by plaintiff's contention that the Louisiana statute providing for notice by publication but with no provision for registered or other mailing or any other substitute for publication was invalid under the due process clause. Whether the "widow" would have fared better on appeal we will never know.

The intra-family quarrel involved in the Bartgos ${ }^{108}$ case had led to an action in a Colorado court to recover damages from plaintiff's former husband for alleged fraud in inducing her to enter into a property settlement referred to and approved by a Kansas decree granting the wife a divorce. The agreement, however, was not set forth or included in the decree.

In several of the cases discussed above, the decision to deny the petition for certiorari was made by less than all the justices. Another case involving a dissent will be discussed below. The rest of the cases in which dissents were "noted" by one or more of the justices to the certiorari denial involved questions of federal taxation, ${ }^{109}$, labor, ${ }^{110}$ mo-

107. 243 U.S. 90 (1917).

108. 210 P.2d 600 (Colo. 1949).

109. Cobb v. Commissioner of Internal Revenue, 173 F.2d 711 (6th Cir.), cert. denied, 338 U.S. 832 (1949), Justices Black and Jackson dissenting. Cobb had given income producing realty to his daughters to assist them in early married life and to reduce his income taxes. Subsequently he was notified of a gift tax deficiency and employed an attorney to petition for reduction of the deficiency. Cobb then tried to deduct the attorney's fees as "ordinary and necessary expenses" within $\$ 23$ (a) 2 of the Internal Revenue Code on grounds that they were paid for the production of income and for the management, conservation and maintenance of property held for the production of income since income producing securities were sold at loss to pay the deficiency.

The Court of Appeals held that the attorney's fees were not deductible within meaning of $\$ 23 a(2)$ since the giving away of property does not produce income to donor or constitute either management or conservation of property and the expense of attorneys' fees was in proximate relation to the gifts and not the production of income or the management of property. The court found the argument that the gift was to reduce taxes and increase family property specious since Cobb and his daughters were not a taxable unit.

110. International Union, U.M.W., v. United States, 177 F.2d 29 (D.C. Cir.), cert. dentied, 338 U.S. 871 (1949) (Justices Black, Reed and Douglas dissenting). The United States brought contempt proceedings against John $L$. Lewis and the United Mine Workers for disobeying a temporary restraining order enjoining the 
nopoly, ${ }^{111}$ infringement, ${ }^{112}$ eminent domain, ${ }^{113}$ jury trial, ${ }^{114}$ self-in-

continuation of the 1948 strike in the bituminous coal industry. At trial, the government introduced evidence to the effect that the walkout had been concerted and under the control of Lewis and that the union had not exercised whatever powers it had at its disposal to get its members back to work. The defendants contended that there had been no "strike" and therefore they were not liable for any work stoppages. The district court found for the government and the Court of Appeals for the District of Columbia, in 177 F.2d 29 (1949), affirmed the judgment and the fines of $\$ 1,400,000$ and $\$ 20,000$ levied on the UMW and Lewis respectively.

State v. Casselman, 69 Idaho 237, 205 P.2d 1131, cert. denied, 338 U.S. 900 (1949) (Justices Black, Reed and Burton dissenting). Employees of Western Electric were indicted and convicted for violating the Idaho Secondary Boycott Act, which outlaws secondary boycotts in "labor disputes" but fails to define the term "labor dispute." The defendants during labor difficulties between them and Western Electric had picketed the building of the Mountain States Telephone and Telegraph Co. with banners which did not indicate against whom they were picketing. As a result, the employees of the Mountain States stopped work. Western Electric, which is located in the same building, provides the equipment for Mountain States' operation and both are subsidiaries of American Telephone and Telegraph, although they negotiate with the labor unions representing their employees on an individual basis. The Idaho Supreme Court affirmed the convictions, holding the statute sufficiently definite to meet constitutional objections since it was in pari materia with the state civil injunction statute enacted the same day which defined "labor dispute." The court also refused to "pierce the corporate veil" and found that the picketing in fact constituted a secondary boycott.

Carroll v. Celanese Corp, 205 Ga. 493, 54 S.E.2d 221 (1949), cert. denied, 338 U.S. 937 (1950) (Justice Black dissenting). The issue presented in this and six companion cases which the Supreme Court was asked to consider on certiorari was whether a conviction for contempt for violating a labor injuction against mass picketing vecame moot when the labor dispute was settled.

111. Turner Glass Corp. v. Hartford Empire Co., 173 F.2d 49 (7th Cir.), cert. denied, 338 U.S. 830 (1949) (Justice Black dissenting). Hartford Empire was found guilty of violating the antitrust laws by engaging in conspiracy, combination and monopoly in obtaining and licensing patents in glass making machinery and in limiting and restricting the use of the machinery. On the basis of this conviction, Turner brought a triple damage action for $\$ 7,000,000$, claiming that the restrictive licensing policy of Hartford under their patents and royalties and the license fees paid by Turner to Hartford during period of the conspiracy placed Turner at a competitive disadvantage which directly caused injury and damage to Turner's business and property in violation of Sections 1 and 2 of the Sherman Act. The trial court found that the evidence failed to establish that defendant caused any damage to plaintiff's business and/or property. The Court of Appeals for the Seventh Circuit affirmed, holding that in order to recover damages for violations of the Sherman Act under Section 7, Turner had to show that it was injured and the sole fact that Hartford had been adjudged guilty in another case was of no help to Turner in the absence of proof, lacking in this instance, that it sustained personal pecuniary damage.

The court stated further that the license agreements under which Turner received rights to use leased machinery were not inherently illegal since they did not necessarily involye doing anything illegal. The fact that Hartford was found guilty of violating the Sherman Act for entering into illegal cross licensing agreements did not affect the enforceability of these agreements.

A comment in 63 HARV. L. REV. 907 (1950) points out the difficulty of meeting the rigid requirements of proof in civil actions under the Sherman and Clayton Acts where potential liability is extensive as compared to the relatively trivial liability in criminal actions against offending corporations. As to the results of civil actions, see Lockhart, 31 MINN. L. REv. 507, 571 (1947).

112. Ric-Wil v. Kaiser Co., 179 F.2d 401 (7th Cir.), cert. denied, 339 U.S. 958 (1950) (Justice Black dissenting.) Ric-Wil sued Kaiser for infringing its patents covering a conduit system and its improvements adopted for use in the transmission of steam and other liquids. The trial court found for Ric-Wil and the Court of Appeals, after modifying the judgment in so far as it directed an accounting by Kaiser, affirmed.

Charles Peckat Mfg. Co. v. Jacobs, 178 F.2d 794 (7th Cir. 1949), cert. denied, 339 U.S. 915 (1950) (Justice Black dissenting). Peckat sued Jacobs for infringement 
crimination and right to counsel, ${ }^{115}$ extradition, ${ }^{116}$ interstate com-

of a patent covering an outside sun visor for automobile windshields. The trial court found that Peckat's patent had been anticipated by a prior patent and prior uses. The Court of Appeals reversed, holding the patent valid and infringed.

113. Towa-Wisconsin Bridge Co. v. United States, 84 F. Supp. 852 (Ct. Cl. 1949), cert. denied, 339 U.S. 982 (1950) (Justices Black and Reed dissenting). The United States constructed a navigation dam on the Mississippi River which raised the water level above the ordinary high water mark. As a result, wooden trestle bridges across sloughs adjacent to the main channel were so weakened as to become inadequate to withstand even normal flood conditions and had to be rebuilt. The sloughs themselves were not improved or maintained by the United States for commercial navigation. The Court of Claims awarded Iowa-Wisconsin, the owner of the bridges, damages on the theory that although the dam was constructed to improve navigation, the sloughs traversed by the bridges are not navigable watercourses of the United States. The government had taken the position that the trestle bridges were over navigable waters and therefore any damage to them resulting from navigation improvements was not compensible.

114. State v. Bridges, 231 N.C. 163, 56 S.E.2d 397 (1949), cert. denied, 339 U.S. 939 (1950) (Justice Douglas, dissenting). Bridges was indicted for murder in the first degree and entered a formal plea of not guilty. At trial his defense was conducted on the theory that a second degree verdict would satisfy the ends of justice and he indicated in response to a question by the trial judge that he was not contending he should be acquitted. In charging the jury, the judge spoke of the "cloak of innocence" surrounding the defendant but at the end put to the jury the choice of first or second degree murder. Bridges was convicted of the former and sentenced to death. The North Carolina Supreme Court affirmed over a bitter dissent by one judge who felt the whole issue of guilt or innocence should have been left to the jury.

Flowers v. Mississippi, 41 So.2d 352 (1949), cert. denied, 339 U.S. 946 (1950) (Justices Black and Douglas dissenting). The defendant, a Negro, was indicted and convicted on a charge of having shot one of a group of white men who had come to his home to warn him to leave the community. On appeal he contended unsuccessfully that he was deprived of his constitutional rights because no Negro's names were listed in the grand jury box and only one Negro was empanelled for the petit jury.

115. People v. Perez, 300 N.Y. 208, 90 N.E.2d 40 (1949), cert. denied, 339 U.S. 916 (1950) (Justice Black dissenting). Perez was arrested, held for 24 hours and then brought before a judge and committed as a material witness in connection with a murder. After five days of consistent questioning without an attorney being present on his behalf he confessed to committing the crime. After being convicted Perez challenged the refusal of the trial court to instruct the jury that they might consider the delay in arraignment in determining whether the confession was voluntary or not. The New York Court of Appeals affirmed the conviction holding inter alia that the five day commitment as a material witness was valid since Perez had admitted knowledge of circumstances surrounding the murder.

Moore v. Mississippi, 207 Miss. 140, 41 So.2d 368, cert. denied, 338 U.S. 844 (1949) (Justice Black dissenting). Moore was convicted of murder and sentenced to death. On appeal he contended that his confession was made under duress in the absence of attorney or family and that he had not been brought before a committing magistrate promptly. In affirming his conviction, the Mississippi Supreme Court held Moore had voluntarily confessed and that even if there had been a delay in his arraignment, it was immaterial insofar as the admissibility of the confession was concerned.

Miller v. State, 207 Miss. 156, 41 So.2d 375, cert. denied, 338 U.S. 844 (1949) (Justice Black dissenting). This was a prosecution for burglary of an uneducated Niegro of subnormal intelligence. On appeal after conviction, Miller claimed that a confession he had made was involuntary, that he had been held incommunicado, that he had no lawyer when arraigned and that the court failed to appoint one. The Mississippi Supreme Court held that his confession was not involuntary and that since the defendant did not request an attorney he waived his right to have one appointed.

116. Ex parte Quillian, 152 Ohio St. 368, 89 N.E.2d 493 (1949), cert. denied, 339 U.S. 945 (1950) (Justice Douglas dissenting). See text at note 44, supra. 
merce, ${ }^{117}$ and the powers of a Four Power military tribunal. ${ }^{118}$ Five of these were on the miscellaneous docket. ${ }^{119}$ All appear to present important questions although whether there were persuasive reasons for denying review under the Court's rule could, in most of them, be determined only by a close examination of the record. In any event, there was a difference in the judgment of the justices in all of them.

Previous reference has been made to the difficulties connected with the examination of the cases on the miscellaneous dockets in which certiorari was denied. One case, however, is fairly well known and warrants mention. In 1925 Tony Marino, at the time 18 years old and a recent immigrant, unable to understand English, was arrested and indicted in Illinois on a charge of murder. When he was brought before the trial court the arresting officer served as an interpreter and no attorney appeared in his behalf. He pleaded guilty and was summarily sentenced to life imprisonment. Twenty-two years later in 1947 Marino filed a petition for a writ of habeas corpus in the circuit court of Winnebago County seeking release on the ground that his constitutional rights had been violated at the time of sentence. The circuit court quashed the writ and Marino then filed a petition in the United States Supreme Court for a writ of certiorari. At this point, the Attorney General of Illinois entered a confession of error and the Supreme Court, on the basis of this confession and "the undisputed facts" described above, reversed and remanded in a per curiam opinion. ${ }^{120}$ Justice Rutledge in a concurring opinion joined in by Justices Murphy and Douglas stated that the case presented "a flagrant example of dep-

117. Kenosha Motor Coach Lines v. Public Service Commission, 254 Wis. 509, 37 N.W.2d 78, appeal dismissed, 338 U.S. 805 (1949) (Justices Black and Douglas dissenting). Kenosha brought an action to set aside an order of the Public Service Commission of Wisconsin, directing an electric railroad not part of a general steam railway system and not owning or operating properties outside the State to restore an abandoned connecting interstate freight service between points within Wisconsin. The Wisconsin Supreme Court reversed a judgment setting aside the order on the grounds that the Commission had jurisdiction since the federal government had not preempted the field by the Interstate Commerce Act and the order was not discriminatory nor did it interfere with interstate commerce.

118. Flick v. Johnson, 174 F.2d 983 (D.C. Cir.), cert. denied, 338 U.S. 879 (1949) (Justice Black dissenting). Flick was tried and convicted by a Four Power Military Tribunal established in Germany to try war criminals. He then petitioned for a writ of habeas corpus in the United States District Court for the District of Columbia challenging the validity of the sentence imposed. The court dismissed the petition and the Court of Appeals affirmed on the ground that the tribunal, although consisting entirely of Americans appointed by the United States military government, was international since its power and jurisdiction arose out of the joint sovereignty of the four victorious powers.

119. State v. Bridges, supra note 114; People v. Perez, supra note 115 ; Ex parte Quillian, supra note 116 and two cases the authors were not able to find; also one case on the appellate docket in which a dissent was noted was not discovered.

120. Marino v. Ragen, 332 U.S. 561 (1947). (The case was remanded because the Attorney General stated that habeas corpus is the proper remedy in Illinois.) 
rivation of due process" ${ }^{121}$ and went on to attack the complex Illinois state procedure for affording relief in such cases. Justice Rutledge complained that only in the few instances where a confession of error was entered did the aggrieved petitioner have a chance to have the wrong committed against him remedied. But the Justice was excessively optimistic. Upon remand, the circuit court held a hearing and once more quashed the writ. Marino then sought another writ of certiorari from the Supreme Court which was denied over dissents by Justices Murphy, Douglas and Rutledge. ${ }^{122}$ As his next move he filed petitions for habeas corpus and a writ of error in the Illinois Supreme Court, both of which were disposed of adversely to him in September 1949. ${ }^{123}$ For the third time Marino went to the Supreme Court of the United States and certiorari was denied again. ${ }^{124}$ The net result is that although 9 Supreme Court justices went on record as recognizing that Marino was denied "the due process of law which the 14th amendment requires," ${ }^{125}$ and the Attorney General of Illinois agreed, after 25 years the unhappy petitioner presumably still remains behind prison walls. The Supreme Court disposed of this situation with two words for the record: "certiorari denied." It may be argued that certiorari should have been granted at the 1948 term but it would seem a sufficient answer that the Court does not correct error by repeating it.

Of the long list of cases each term in which certiorari is denied, it is certain that a large number never should have been brought to the Court's attention. ${ }^{126}$ This is not only true of cases on the miscellaneous dockets but applies, even if not to so great an extent, to those on the appellate docket as well. In some, it is difficult to believe that a competent attorney could sincerely believe that it was in his client's interest to bear the heavy expense of a petition for certiorari. If consideration for the Court is due from members of its bar, then this alone might restrain such appeals; furthermore one might suppose that the negligible chance of success would deter most lawyers from seeking

121. Id. at 564.

122. Illinois ex rel. Marino v. Ragen, 336 U.S. 969 (1949).

123. 404 III. 35, 88 N.E.2d 7 (1949) (habeas corpus); 404 I11. 37, 88 N.E.2d 8 (1949) (writ of error). The court held that the Supreme Court's denial of certiorari governed the petition for a writ of habeas corpus since the same record was presented on both occasions. In the case of the petition for a writ of error, it was based on the common law record alone in which it did not appear affirmatively that Marino was not represented by counsel.

124. Illinois ex rel. Marino v. Ragen, 339 U.S. 921 (1950).

125. 332 U.S. 561, 562 (1947).

126. "During the past term of the Court only about $15 \%$ of the petitions for certiorari were granted, and this figure itself is considerably higher than the average in recent years. While a great many of the $85 \%$ that were denied were far from frivolous, far too many reveal a serious misconception on the part of counsel concerning the role of the Supreme Court in our federal system." Chief Justice Vinson, Work of the Federal Contrs, an address before the American Bar Association, Sept. 7, 1949, printed in 70 Sup. Ct. XIII, XIV (1949). 
review of the issues in cases trivial from the view of national interest. And yet, each year, the Justices and their clerks must consume valuable time in examining extensive records in such cases. Here are a few samples which, in the authors' judgment, readily fall into this category.

In Horn $v$. Chicago, ${ }^{127}$ an abutting property owner, claiming damages from the construction of a viaduct by the city, felt aggrieved by the application to his case of an Illinois five-year statute of limitations. He sought a review by the Supreme Court by appeal which was dismissed or, if treated as a petition for a writ of certiorari, denied. ${ }^{128}$ In Commissioners v. Russell, ${ }^{129}$ it was held that the building and maintenance of a courthouse and jail over a period of 27 years was substantial compliance with conditions in a deed so as to avoid a forfeiture where the deed failed to specify the period of compliance. Good Holding Co. v. Boswell, ${ }^{130}$ raised a run-of-the-mine question of malicious prosecution. The manager of a business establishment reported to law enforcement officers the findings of a detective agency accusing plaintiff, an employee, of theft. He omitted, however, to reveal other facts within his knowledge which threw grave doubt on the question of plaintiff's guilt. In an action against him for malicious prosecution, the question of malice was left to the jury which found against defendant. The court held, on appeal, that the evidence sustained the finding and that the issuance of a warrant and filing of information against accused neither negatived malice as a matter of law nor conclusively established the existence of probable cause where the person responsible for the proceedings failed to make a full and fair disclosure to the prosecuting authorities. In another case of malicious prosecution, the Court of Appeals for the Fourth Circuit had held that a compromise settlement by a defendant in a criminal prosecution estopped him from subsequently contending that the proceedings had been instituted without probable cause. ${ }^{131}$ In a case coming up from Kentucky, ${ }^{132}$ a Sewer District wanted the Supreme Court to review a case in which the Court of Appeals of Kentucky declined to apply a statute of the State in a manner which pretty clearly would have amounted to the impairment of a contract obligation or a taking of property without compensation. And in a case from South Carolina, an action for wrongful death, it was contended that the evidence on punitive damages was insufficient

127. 403 I11. 549, 87 N.E.2d 642 (1949), cert. denied, 338 U.S. 940 (1950).

128. Ibid.

129. 174 F.2d 778 (10th Cir), cert. denied, 338 U.S. 820 (1949).

130. 173 F.2d 395 (4th Cir.), cert. denied, 338 U.S. 815 (1949). (1950).

131. Leonard v. George, 178 F.2d 312 (4th Cir. 1949), cert. denied, 339 U.S. 965

132. Louisville and Jefferson County M. S. Dist. v. Bond Bros., 228 S.W.2d 655 (Ky. 1949), cert. denied, 339 U.S. 943 (1950). 
to support the jury's verdict in favor of the plaintiff and this raised a question which the Supreme Court ought to decide. ${ }^{133}$

On the other hand, the judgment of men, whether Supreme Court justices, practicing lawyers or Law School professors and students varies to such an extent that the ultimate appraisal of a case is frequently not too obvious. For example, Justice Black recorded his dissent in Bernstein v. Ems, ${ }^{134}$ a case classified by the authors as "trivial." It involved, on the face of it, a relatively elementary problem of tort law. The Court of Appeals for the Second Circuit had reversed a decision on a verdict rendered against a lessor of business premises in favor of a business guest who had been hurt when a lighting fixture fell on him. The court held that there was nothing in the record to show that the defendant knew or by the exercise of reasonable care could have discovered the defect, even if it were conceded that, as the trial judge had held, the lessor had retained "control" over the ceiling and fixtures in the lease between itself and its tenants. There appears to be no deviation from New York law contrary to the rule of Erie R. R. v. Tompkins. On the face of it, the case looks like dozens of other tort cases picked at random out of almost any advance sheet. And yet, at least one of the nine justices, after examining the record, thought it merited Supreme Court consideration, notwithstanding the unanimous decision of one of the most distinguished courts in the nation. Mr. Justice Black's known respect for jury findings may explain his position.

A question may be important in the sense that it involves a question of policy which clearly affects our way of life or our institutions, but still not be "important" in the sense that it makes a legitimate claim upon the Supreme Court for decision. Saint Lo Construction Co. $v$. Koenigsberger ${ }^{135}$ is an example. Here plaintiff brought an action to restrain defendant from building anything but a residential building on property covered by a restrictive covenant. Prior to this action, defendant's predecessor in title had unsuccessfully sought to cancel the covenant on the grounds that the neighborhood had changed. The district court held, in the absence of new evidence on "change," that the prior decision was conclusive and the injunction issued. The Court of Appeals for the District of Columbia affirmed.

Now here is a question of some importance. Judge Edgerton dissented on the ground that the legal validity of a restrictive covenant did not necessarily require enforcement by injunction-a balancing of

133. Jennings v. McCowan, 215 S.C. 404, 55 S.E.2d 522 (1949), cert. denied, 70 Sup. Ct. 494 (1950).

134. 174 F.2d 880 (2d Cir.), cert. denied, 338 U.S. 873 (1949).

135. 174 F.2d 25 (D.C. Cir.), cert. denied, 338 U.S. 821 (1949). 
equities might call for denial of equitable relief although the aggrieved landowner might be entitled to damages. The problem has broad policy implications and has evoked considerable discussion. ${ }^{136}$. But the further question may be raised whether it is the sort of case which the Supreme Court should review. The authors classified the case as "important" under the Rules of the Supreme Court relative to review of cases from the Court of Appeals for the District of Columbia. But a good argument could be made that that court might well be made the court of last resort for such questions in so far as they arise in the District. Certainly its dignity is comparable to that of the supreme courts of the states.

So too in United States $v$. Walker, ${ }^{137}$ it was held, by a divided court, following the ancient common law rule, that a wife could not testify against her husband without his consent in a criminal trial where the offense was committed against a third person. The rule has been abrogated in many states ${ }^{138}$ and the Supreme Court has permitted a wife to testify in favor of her husband, ${ }^{139}$ thus making a crack in the theory of the "unity" of husband and wife. Although a conflict between decisions in the different circuits ${ }^{140}$ would have afforded the Supreme Court an excuse to review, had it so desired, it is not difficult to maintain that the issue, though important, does not carry with it national significance of such magnitude as to require a grant of certiorari.

\section{Conclusion}

What of significance is suggested by this limited, and admittedly inadequate look at the work which the Supreme Court did not do during the 1949 term? Here were more than a thousand litigants who vainly sought review of their legal troubles by the Court. Many of them are in jail and will remain there for years; some have been executed. To be sure, from experience, from random sampling, from confidence in the integrity and ability of the Court as an institution and the justices who sit on it, we may be sure that a large number of these cases had no merits which could conceivably justify review by the Supreme Court. Some of this litigation should never have been instituted in the first place and much of it was carried so far as a petition for a

136. The principal case is commented on in 62 HARV. L. REv. 1394 (1949). On the general problem, see Pound, The Progress of the Law, 1918-1919, 33 HARv. L. REv. 813, 821 (1920).

137. 176 F.2d 564 (2d Cir.), cert. denied, 338 U.S. 891 (1949).

138. See 2 Wigmore, Evidence $\S 488$, n. (3d ed.) and see 38 Geo. L.J. 316 (1950).

139. Funk v. United States, 290 U.S. 371 (1933).

140. Compare Yoder v. United States, 80 F.2d 665 (10th Cir. 1935) with Paul v. United States, 79 F.2d 561 (3d Cir. 1935). 
writ of certiorari only because of the ignorance of the petitioner or the incompetence or venality of his lawyer.

Nevertheless, 64 important cases is not a negligible number. Of the many reasons which could have influenced the justices individually or collectively to deny the petition in these cases, we shall never know which ones in fact were persuasive. Indeed, in a large number of these cases, it is impossible to determine what considerations indicating the propriety of denial were present without reading the entire record and doing over the work done by the justices and their law clerks. Hidden away in the middle of the record might be the clue to a perfectly legitimate basis for denying the petition. It is certain that one cannot state the absence of such basis merely from reading the opinion of the court below.

But when all allowances are made and every consideration weighed, one can scarcely avoid a troubled feeling about the 64 cases. Take Lapides, Trumbo, Stuyvesant Town, the Baltimore Radio Show. These cases raised the most vital constitutional problems that could be presented to any court in a democratic country. But it was impossible to get them reviewed by the Supreme Court. Whatever the reasons, one obvious question almost shouts for an answer: Can any reason be adequate to justify the Court's failure to face these questions and settle them?

In a highly confused and mixed up world where much of it is run on the principle of the jungle, it may be that an important need for the nation claiming the top rung of the democratic ladder is one of institutional soul-searching self-analysis, by the Supreme Court, the Congress which is supposed to be the champion of the common man, and perhaps even by the latter himself. In any form of government, there must be a last word some place. A big government is necessarily a complicated one and an awful lot of little people get hurt in the shuffle. We cannot expect from one government agency of nine men and a very small staff complete review of the legal troubles of every one of our hundred and fifty million people who ask for it. But it is disconcerting when the Court will review a controversy over a patent on a pin ball machine ${ }^{141}$ while one man is deprived of his citizenship and another of his liberty without Supreme Court review of a plausible challenge to the validity of government action. What we can hope for, reasonably, is that when a little man raises a big issue, that issue will, at least, get the judicial consideration which its importance deserves. It is bad if the issue is resolved the wrong way. But on highly controversial issues, the judg-

141. Faulkner v. Gibbs, 338 U.S. 267 (1949), decision below, 170 F.2d 34, cert. granted, 336 U.S. 935 (1949). 
ment of men will differ and that is one reason we have the Supreme Court. What is very bad indeed is the silent treatment by the Court of an issue which is obviously one of far-reaching public concern.

Perhaps the most startling fact from the breakdown of the denials of certiorari on the appellate docket is the large number of civil rights cases and the large proportion of them which may reasonably be classified as important. Of the civil rights cases which the Court did review, 15 were decided by a divided court. In 14 of the 15 the asserted right was denied. This "broad jump to the right" is described by Professor Frank as "the most important new development of the year." The record on denials appears to confirm the conclusion of the "broad jump." One may speculate as to the results of the 15 civil rights cases in which the Court divided if Justices Rutledge and Murphy had lived and Justice Douglas not been absent most of the term. A similar speculation is permissible as to the 27 denials of important civil rights cases. The speculation has point in the light of the voting record of the two new justices in the civil rights cases in which they participated. ${ }^{\mathbf{1 4 2}}$

It would appear that the Court's practice in handling certiorari problems raises several rather specific questions of which the following are samples:

(1) Should the Court be accorded such wide powers in controlling its business?

(2) Should the Court deny certiorari without giving its reasons, however briefly?

(3) Should the Court deny certiorari if the case involves an important question, regardless of other considerations which suggest denial?

(4) Are there not preferable ways of regulating the fiow of work of the Court and thus reducing its work to manageable limits, for example :

(a) by shutting off all FELA and bankruptcy cases except perhaps where there are conflicts between the circuits;

(b) by re-examining the basis and reasons for diversity jurisdiction with a view to eliminating petitions to the Supreme Court in such cases and making the Courts of Appeal the final court for the various contract, tort, stockholders' family squabbles, and other garden variety litigation that clogs the dockets under diversity jurisdiction; $87 \%$ of the time, Minton, $80 \%$. See 18 U. of CrI. L. REv. 1, 38 (1950). 
(c) by devising some method for disciplining attorneys for filing obviously frivolous petitions, if only by admonition in specific cases, thus exposing the offender to the professional embarrassment which he deserves.

(5) Should the Court be enlarged?

In 1928, (then) Professor Frankfurter commented on the Judiciary Act of 1925: "A change so drastic as that wrought by the new Act in the discretionary powers of the Court must await its vindication from actual practice." 143 It is by no means clear that the actual practice during the 1949 term has done so.

143. Frankfurter and Landis, The Business of the Suprene Court, pp. 286287 (1928). 